\title{
The relationship between decision-making factors and 'festivalscapes' with visitor loyalty: Evidence from a South African national arts festival
}

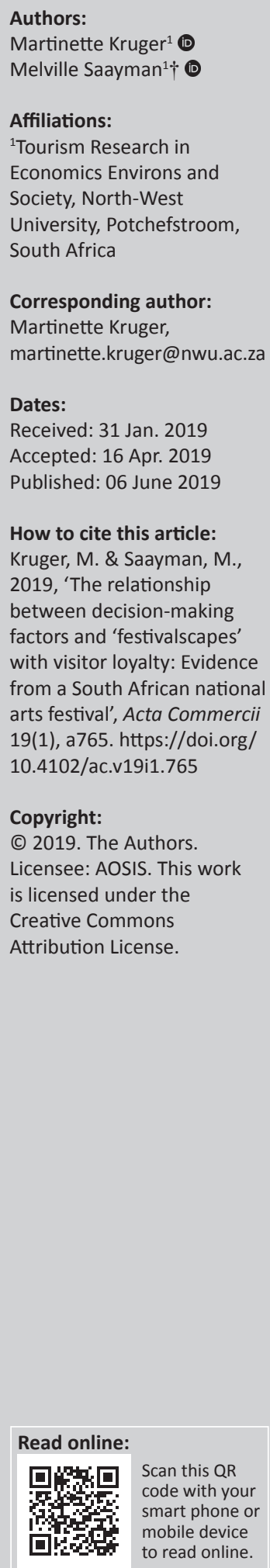

Orientation: The escalating number of festivals leads to competition, with festivals finding themselves in the decline phase of their product's lifecycle. In South Africa, many festivals choose to terminate, but in the case of Aardklop, the festivals chose to undergo a rebranding and repositioning process. The question is to what extent did the rebranding process influence visitors' decision to attend the festival?

Research purpose: This research determined the key 'festivalscape' and decision-making factors, including the rebranding and repositioning of the festival, and established the relationship between these factors and visitors' loyalty to Aardklop.

Motivation for the study: Although Aardklop and its offerings are clearly popular among the public, to date, no research attempts have been made to determine which factors influence visitors' loyalty towards the festival.

Research design, approach and method: The research was quantitative, and a survey was conducted in 2017 where 498 completed visitor questionnaires were obtained. Factor analyses identified the main 'festivalscape' and decision-making factors, while structural equation modelling was used to test the relationship between the factors and festival loyalty.

Main findings: The results showed that a combination of 'festivalscape' and decision-making factors influence loyalty especially the distinct offerings, festival features and experiences.

Practical/managerial implications: Managerial and marketing implications are made outlining how the distinct festival offerings need to be emphasised as they have the most significant influence on festival loyalty.

Contribution/value-add: This research contributes to a better understanding of the factors that influence visitor loyalty and how these factors can be managed.

Keywords: National Arts Festival; 'festivalscapes'; decision-making factors; festival loyalty; South Africa.

\section{Introduction}

South Africa is a multi-ethnic society, encompassing a wide variety of cultures, languages and religions. Its multicultural makeup is reflected in the constitution's recognition of 11 official languages, which is one of the highest numbers of any country in the world. According to the Official Languages of the Union Act 8 of 1925, Afrikaans (stemming from Dutch) was declared an official language (South African History Online [SAHO] 2018). A study conducted in 2013, using data from the last census in 2011, determined that only $40 \%$ of Afrikaans speakers are white people. The rest of the population consists of other races - black people, mixed race people and Indian, with the majority being mixed race people (News24 2017).

Post-apartheid South Africa (after 1994) has seen a loss of preferential treatment for Afrikaans by the government in terms of education, social events, media (television and radio) and general status throughout the country because it now shares its place as official language with 10 other languages (News24 2017; SAHO 2018). As a result, the Afrikaans-language festivals came into existence during what could be termed the new 'language struggle' of the 1990s, when the Afrikaans-speaking population began to fear the extinction of its language and culture under the democratic government's 'new South Africa' dispensation and its expressed preference for English (Hauptfleisch 2006; SAHO 2018). 
With more than 600 festivals held annually across the country, it is difficult to assess accurately how many festivals are devoted to the enhancement of the arts in Afrikaans. Over 10 years ago, Kitshoff (2005) noted a significant increase in Afrikaans festivals in South Africa. At the time of writing, the number of specifically Afrikaans festivals had probably more than doubled since 2001 (Hauptfleisch 2006). The oldest and best known of these is the Klein [Little] Karoo National Arts Festival (KKNK), first hosted in 1995. The KKNK was the first festival that expressed its sole purpose to be the promotion of the Afrikaans language and culture. To achieve this, it was conceived as a distinctively theatrical event that was meant to express, display and communicate a particular vision of the Afrikaans and 'Afrikaner' cultural context to the public at large, directly and indirectly (Hauptfleisch 2006). Its example opened the way for the Aardklop (Earth pulse or beat) National Arts Festival (hereafter referred to as Aardklop), which seeks to emulate the work of the KKNK in the northern part of the country. Each year in October, the festival is held in Potchefstroom, located in the North-West province. The Aardklop programme offers theatre productions, music performances, visual arts exhibitions and lifestyle events for the duration of the festival (Aardklop 2018).

However, the escalating introduction of new festivals to South Africa's arts festival calendar overstocks the festival market and the increased competition is having a direct impact on the sustainability of these festivals (Kruger \& Saayman 2016:392-408; Pretorius, Viviers \& Botha 2014: 159-182; Van Heerden \& Saayman 2018; Van Zyl \& Strydom 2007:121-143). Economic difficulties are also putting a strain on disposable income, visitor characteristics are changing and it is becoming progressively more difficult to find sponsors. In many countries, the arts are, therefore, under increasing financial pressure (Snowball \& Antrobus 2001: 752-766; Snowball \& Willis 2006:43-56). This is particularly true of developing countries like South Africa, where the arts must compete with sectors such as housing, education and health for very limited public funds (Kruger \& Saayman 2016:392-408). A further problem is that resources are still mostly apportioned along the lines of race and wealth. Many art patrons believe the government ought to provide financial support (Kruger \& Saayman 2016:392-408). However, although the South African government acknowledges the role of the arts in 'enhancing the country's identity and distinctiveness', encouraging 'nation building' and assisting in personal development by increasing self-confidence and promoting self-esteem, the primary focus of policy since 1994 has been on job creation and the financial benefits that the arts provide, rather than on their less tangible benefits (Snowball 2005:107-125). As a result, the arts in South Africa are becoming increasingly dependent on private sponsors.

Aardklop is South Africa's most popular arts festival (as voted for by the public) and won the coveted Fiësta award in 2016 and 2017 (KykNET 2017). Although the festival and its offerings are thus clearly popular among the public, to date, no research attempts have been made to determine which 'festivalscapes' and decision-making factors influence visitors' loyalty towards the festival. In an attempt to regain a competitive advantage, Aardklop underwent a rebranding and repositioning process in 2016. This implied a new festival logo, vision and mission; a new board of directors and organising committee; a more vibrant and innovative festival programme with flagship productions and moving to the original festival grounds. The research, therefore, also sought to determine whether the rebranding and repositioning of the festival played a role in visitors' decision to attend the festival and their consequent loyalty towards Aardklop. The goal of the research is, therefore, to fill the gap in the South African arts festival literature by (1) determining the key 'festivalscape' and decision-making factors (including the rebranding and repositioning of the festival) that influence visitors' decision to attend Aardklop, and (2) establishing the relationship between these factors and visitors' behavioural intentions, that is, the likelihood of positive referrals and returning in the future (loyalty).

This approach will provide festival organisers and marketers with insight into the most influential factors that play a role in festival visitors' decision to attend the festival, as well as to what extent the festival can manage and sustain visitor loyalty. Moreover, the influence of the rebranding and repositioning of the festival on visitors' future intentions can be established, which can assist not only the organisers of Aardklop but also those of other festivals that are in the process of rebranding (or planning to rebrand) their event.

\section{Literature review}

Tourism and events literature specifies that decisionmaking is a process involved with a number of interactive factors, including motivation, searching for information, the attractiveness of destinations/events/festivals, social and psychological influences and constraints, and negotiation (Getz 2005). Chen (2011) stipulates that closely examining all of these interactive factors involved in the decision-making process at the same time may better explain and predict festival visitors' behaviour than those factors being studied independently. Attempts in the tourism literature to develop a global decision-making process stems, to a large extent, from three studies that laid the foundation, namely those of Moutinho (1987), Um and Crompton (1991) and Woodside and MacDonald (1994). Collectively, these studies have shown that the tourist decision-making process consists of three sets of variables: internal input, choice sets and postvisit evaluation. Based on this, Figure 1 offers a conceptual framework for this process.

In the case of a one-off event like an annual festival, the decision-making process starts when visitors identify a need to attend it, look for information about its location and what it offers, consider its cost, weigh up the alternative festivals and, finally, make a choice (Kruger \& Saayman 2012:147-162). The need to attend is represented by the internal input and refers to visitors' socio-demographic, behavioural and psychographic characteristics. The Afrikaans national arts 


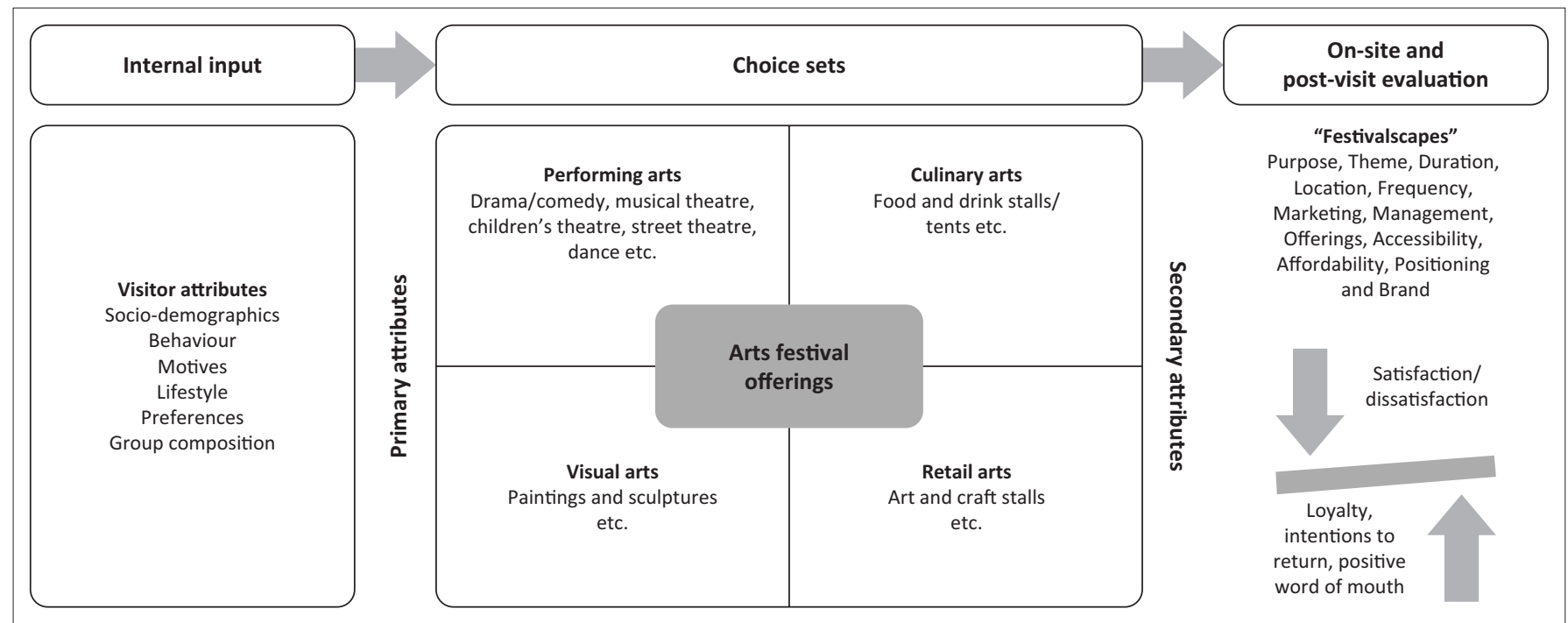

Source: Authors' own compilation based on Kruger and Saayman (2018c), Moutinho (1987), Um and Crompton (1991), Viljoen, Kruger and Saayman (2018) and Woodside and MacDonald (1994). See Kruger, M. \& Saayman, M., 2019, 'The relationship between decision-making factors and 'festivalscapes' with visitor loyalty: Evidence from a South African national arts festival', Acta Commercil 19(1), a765. https://doi.org/10.4102/ac.v19i1.765 for more information

FIGURE 1: Conceptual framework for festival visitors' decision-making process.

festival visitor can be classified as mostly Afrikaans speaking, well educated, originating mainly from either the host province or Gauteng (the economic hub of the country), with a high average spending and a high attendance at shows and exhibitions of products (Botha, Slabbert \& Viviers 2014:324-348; Kruger \& Saayman 2016:392-408; Pretorius, Viviers \& Botha 2016:290-305; Viviers \& Slabbert 2014:1-18). However, the visitor interested in the socialisation aspect of attending festivals is also continually present.

In a review of 46 festival motivation articles (from which 70 motives were extracted), the main recurring motives were socialisation, family togetherness, escape, novelty, excitement and cultural exploration (Maeng, Jang \& Li 2016:16-25). From this review, it appears that festival visitors are more motivated by push factors. In a South African arts festival context, most of the studies identified 'festival attributes', followed by 'escape and relaxation' and 'festival productions', as the main motives for attending the festivals. These were followed by 'festival amenities and novelty' and, lastly, 'socialisation' (Botha, Viviers \& Slabbert 2012:22-44; Kruger \& Saayman 2012:147-162; Kruger \& Saayman 2016:392-408; Kruger, Saayman \& Ellis 2010:1-26; Kruger, Saayman \& Ellis 2011: 511-526; Saayman 2011:109-120; Van Zyl \& Botha 2003: 213-222; Viviers, Botha \& Perl 2013:211-229; Viviers \& Slabbert 2014:1-18). Contradicting the observation from international studies that push motives play a bigger role in festival and event attendees' decision to attend, it appears that pull motives, in other words, the distinct nature, characteristics and offerings of the festival, are more prevalent in South African festival attendance (Kruger \& Saayman 2018c).

Once the need to attend a festival is established, the consumers will look for a festival that will satisfy their need. It is during this phase where the choice sets come into play. In the case of festivals and events, the choice sets resemble the distinct characteristics of the festival and the festival offerings. Because these aspects shape the visitors' decision-making process, they form the core of Figure 1. Festival attributes such as the purpose, theme and location of the festival are important characteristics, as they influence the offerings, the visitor experience and how the latter is managed, branded and marketed, in other words, the 'festivalscapes'. The art festival offerings appear in the centre of Figure 1. Here, we distinguish between primary and secondary offerings. The primary art enhancement attributes (the performing and visual arts) support the festival's main purpose directly (Pretorius et al. 2016:290-305; Van Zyl \& Strydom 2007: 121-143). These primary attributes should be the most prevalent offerings at the festival. The secondary art enhancement attributes (the retail and culinary arts) support the festival's main purpose indirectly. The culinary and retail arts form part of the traditional flea market at festivals. In this regard, Kruger and Saayman (2018c) found that stalls play a significant part in visitors' arts festival experience, whereas Viljoen et al. (2018) revealed the importance of enhanced culinary offerings at national arts festivals. Considering the significant number of arts festivals in the country and the ever-increasing competition among these festivals for visitors and sponsors, it is essential that arts festivals excel in their offerings and reinvent and evaluate their offerings continuously based on the changing needs of the market.

The end goal of every art festival is to be chosen by visitors over other arts festivals. Previous research regarding the evaluation of 'festivalscapes' in a South African festival context found that the type and nature of the festival and the visitors attracted by it greatly influence the combination and rating of 'festivalscapes'. In their study on an agri-festival, Fourie and Kruger (2015) found that the motive, lifestyle, escape, socialisation and 'festivalscape' factor, as well as agricultural exposure and education, had positive relationships with festival loyalty. In a culinary festival context, Viljoen and Kruger (2019) found that aesthetics, group composition, accessibility and parking, cheese knowledge, festival management, cheese experience, 
convenience, marketing, entertainment and interaction are the most important 'festivalscapes'. Van Zyl (2008) analysed three arts festivals (i.e. KKNK, Aardklop and the National Arts Festival) and identified five festival attributes: festival brands, ticket prices, entertainment activities, food and beverages (refreshments) and transport to venues. Kruger et al. (2010) found that repeat attendance at arts festivals was mainly influenced by general management, productions, services and prices.

After the consumers have attended the selected festival, the final decision-making variable, the post-visit evaluation, becomes relevant and their experience naturally influences future purchasing decisions, in other words, their behavioural intentions. In a festival context, behavioural intentions refer to 'a stated likelihood to return to the festival, to comment on the festival positively, and to recommend the festival to family, friends, and others in the future' (Yang, Gu \& Cen 2011:25-44).

Studies have shown that perceived value and satisfaction precede behavioural intention at festivals (Duman \& Mattila 2005:311-323; Lee 2016:187-196; Lee, Graefe \& Burns 2007:463-481; Yoon, Lee \& Lee 2010:335-342). Quality, value and satisfaction should, therefore, be examined to understand visitors' behaviour and their intention to return (Kim et al. 2018:1-16; Kruger \& Saayman 2017:204-223, 2018a:1-16, 2018b:237-254; Lee et al. 2007:463-481; Yoon et al. 2010: 335-342). It has, furthermore, been suggested that satisfaction leads to customer loyalty, which is frequently represented regarding expenditure, repeat attendance and positive word of mouth (Kruger \& Saayman 2018a:1-16, 2018b:237-254; Smith, Costello \& Muenchen 2010:17-35).

In a South African festival and event context, Kruger and Saayman (2017:204-223, 2018a:1-16, 2018b:237-254) showed that visitors' behavioural intentions can extend beyond positive referrals and return visits. The authors confirmed that behavioural intentions comprise visitors commenting positively on the festival, sharing information or experiences with others, actively searching for and travelling to similar festivals and events, and gaining a deeper appreciation of artistic forms (applied and performing arts). They further found that festival attributes, in other words, the distinct nature of the festival and its offerings as a motive, appreciation of a particular art and sharing of experiences have the strongest influence on the recommendation of a festival and repeat attendance (Kruger \& Saayman 2018a:1-16). In the context of the present study, behavioural intentions will, therefore, be the dependent variable to show which choice set of variables has the most significant influence.

\section{Methodology The questionnaire}

This quantitative research was conducted using a structured questionnaire. The questionnaire was divided into three sections. Section A captured demographic details (gender, home language, age, occupation and home province) and spending behaviour (number of persons paid for, length of stay, times attended and expenditure). This section also captured information that is specific to visitors' behaviour during the festival (preferred accommodation, number of tickets purchased, preferred genres and when the decision was made to attend). The socio-demographic and spending behaviour questions were based on the standardised measuring instrument applied in research at Aardklop and other South African Afrikaans arts festivals (see Botha et al. 2011:142-166; Kruger \& Saayman 2016:16-25; Kruger et al. 2010:1-26,2011:511-526). Section B measured 11 'festivalscape' elements on a five-point Likert scale, where $1=$ not applicable; 2 = not satisfied at all; 3 = satisfied to a moderate extent; $4=$ satisfied to a large extent and $5=$ extremely satisfied. The statements ranged from accessibility, affordability and variety, and were adapted from and based on the works of Fourie and Kruger (2015) and Viljoen, Kruger and Saayman (2017). Section B further measured visitors' behavioural intentions, in other words, whether they would attend the festival again and recommend it to family and friends, on a five-point Likert scale of agreement. Section $C$ asked to what extent specific festival characteristics influenced the respondents' decision to attend the festival (influential decision-making factors). Twenty-four aspects, ranging from the distinct character of the festival, the rebranding and repositioning, as well as the motives for attending, were measured on a five-point Likert scale in which $1=$ not at all; 2 = to a small extent; $3=$ neutral; $4=$ to a large extent and 5 = completely. Many of the motivational items included in Section C, especially 'escape', 'socialisation' and 'festival attributes', were adapted from a variety of studies that specifically focused on the motives of arts festival visitors (see Kruger \& Saayman 2012:147-162; Kruger et al. 2010: 1-26, 2011:511-526; Viviers et al. 2013:211-229). The authors created the statements related to the rebranding and repositioning of the festival. The behavioural intention statements consisted of the likelihood that respondents would (1) recommend the festival to others, (2) positively comment on the festival and (3) attend it again. The three statements were based on the recommendations by Lee et al. (2007), Yang et al. (2011) and Yoon et al. (2010).

\section{Sampling method and survey}

In total, 500 questionnaires were distributed over a period of 5 days (03-07 October 2017) by using simple random sampling; 498 of the returned questionnaires were sufficiently completed to be included in the analysis. All questionnaires were completed at the main festival grounds and at various venues in Potchefstroom, where fieldworkers moved around to minimise bias. Adult visitors were selected randomly as they entered or left these areas, as well as when they were sitting down and relaxing at the various venues. The four fieldworkers were trained to ensure that they understood the aim of the study and the questionnaire, and they could brief respondents about the purpose of the research. Questionnaires were also handed out progressively towards the end of the festival to give a more detailed account of visitor spending. Each fieldworker had 125 questionnaires to distribute 
cumulatively over the 5 days of the festival: 15 on the first day and on the consecutive days 20, 25, 30 and, finally, 35 . According to Krejcie and Morgan's formula (1970), a sample of 384 respondents is seen as appropriately representative for a population $(N)$ of 100000 and will thus validate the results. Based on the figures provided by the festival organisers, approximately 33000 visitors attended the festival in 2017 (TREES 2018). The number of completed questionnaires is greater than required, thereby validating the sample size.

\section{Statistical analysis and results}

The data were captured by using Microsoft Excel $^{\odot}$ and analysed by using SPSS Version 25 (2018) and AMOS Version 25, an added SPSS module (2018). The analysis was done in three stages: a descriptive analysis to profile the respondents; three factor analyses (influential factors and motives to attend the festival, satisfaction with 'festivalscape' elements and behavioural intentions [loyalty]) and a structural equation modelling (SEM) in AMOS to show the relationship between the influential factors, 'festivalscapes' and loyalty.

\section{Profile of respondents}

Almost all the respondents were Afrikaans speaking (95\%). More female (71\%) than male respondents (29\%) participated in the survey. On average, the respondents were 46 years old, originated from Gauteng (41\%) (approximately $150 \mathrm{~km}$ from Potchefstroom) and the host province, North-West (33\%), spent 3 days at the festival and two nights in Potchefstroom, travelled in a group of three persons, bought six tickets for shows and productions (excluding tickets to the festival grounds), spent an average of R3140 per group (approximately US\$290), were financially responsible for two persons during the festival, and had attended the festival 6 times previously. They had heard about the festival via a variety of marketing media, with word-of-mouth recommendations (46\%) being the most influential, followed by television or radio $(45 \%)$. The most preferred genre was comedy productions (74\%).

\section{Ethical considerations}

Ethical approval was obtained from the Ethics Committee of the North-West University (ethical clearance number: EMS24/05/16-02/01). Permission was further obtained from the festival organisers to conduct the research.

\section{Results from the exploratory factor analyses}

The convergent construct validity of the variables in Sections B and C was tested by means of exploratory factor analyses to determine the combination of factors in which the variables were most consistent (Quinlan et al. 2015). Exploratory factor analyses were performed to identify the 'festivalscape' elements that visitors regard as important, as well as on the loyalty and decision-making factors and the influential factors that motivated them to attend. Because it can be expected that there would be correlations between the different factors, an Oblimin rotation with Kaiser normalisation was done to improve the interpretability of the factor structure. The Kaiser-Meyer-Olkin measure of sampling adequacy was used to determine whether the covariance matrix was suitable for factor analysis. Kaiser's criteria for the extraction of all factors with Eigenvalues larger than 1 were used because they were considered to explain a significant amount of variation in the data. All items with a factor loading greater than 0.4 were considered as contributing to a factor, and all items with loadings less than 0.4 were regarded as not correlating significantly with this factor. Any item cross-loading on two factors with a factor loading greater than 0.4 was categorised in the factor where interpretability was best. The reliability of the identified factors, reliability coefficients (Cronbach's alpha) and inter-item correlations were calculated. All factors with a reliability coefficient above 0.6 were considered acceptable for this study. The average inter-item correlations were also computed as another measure of reliability: these, according to Cohen (1988), should lie between 0.15 and 0.55. Factor scores were calculated as the average of all items contributing to a particular factor to interpret them on the original fivepoint Likert scales.

Two exploratory principal component factor analyses were performed on the 11 'festivalscape' elements and the 24 influential motives, whereas confirmatory factor analyses (CFA) were performed on the three loyalty items to confirm the results of the exploratory factor analysis. Tables 1-3, therefore, indicate both the corresponding statement number as used in the questionnaire that loaded under each factor and the factor label abbreviations that are included in the SEM models. The Kaiser-Meyer-Olkin measure of sampling adequacy was 0.79 for the 'festivalscape' factors, 0.93 for the influential decision-making factors and 0.74 for the loyalty factor, respectively, and thus above the commonly recommended value of 0.6. Bartlett's test of sphericity was significant in all three cases: $\chi^{2}(55)=1097.80, p<0.05$; $\chi^{2}(276)=5529.60, p<0.05$; and $\chi^{2}(3)=752.55, p<0.05$, respectively. All items loaded on a factor with a loading greater than 0.4 and all factors had a reliability coefficient above 0.6 ; they were, thus, considered acceptable for this study. The identified factors accounted for $73 \%, 68 \%$ and $80 \%$ of the total variance, respectively. For the CFA, the following goodness-of-fit requirements were followed: a comparative fit index (CFI) closer to 1, root mean square error of approximation (RMSEA) closer to 0 (preferably $\leq 0.08$ ) and a relative/normed $\chi^{2}\left(\chi^{2} / \mathrm{df}\right.$, i.e. the chi-square index divided by its degrees of freedom) between 2.0 and 5.0 mean a good fit for a model (Blunch 2008).

Table 1 shows that four 'festivalscape' factors were identified. Based on the mean values $(\bar{x})$, respondents were particularly satisfied with the gastronomy elements $(\bar{x}=4.29)$, followed by shows and accommodation $(\bar{x}=4.21)$, accessibility and affordability $(\bar{x}=4.11)$ and shopping opportunities $(\bar{x}=3.93)$. The fit indices for the CFA indicated a well-fitted model. The RMSEA value was 0.071 with $90 \%$ confidence (between 0.059 and 0.084 , which is acceptable). The CFI was 0.935 , which also means that it is acceptable. Moreover, the relative or normed $c^{2}$ was 3.830 , which is also acceptable. 
Table 2 shows that five influential decision-making factors were identified. Respondents indicated that festival repositioning $(\bar{x}=4.48)$ greatly influenced their decision to attend the festival. This was followed by festival attractiveness $(\bar{x}=4.42)$, festival rebranding $(\bar{x}=4.03)$, festival getaway $(\bar{x}=4.37)$ and finally art purchasing and well-being $(\bar{x}=3.77)$. It is clear that the repositioning and rebranding of Aardklop had a significant influence on visitors' decision to attend the festival. Overall, the fit indices of the CFA indicated a

TABLE 1: Results from the factor analysis on visitors' satisfaction with 'festivalscapes'.

\begin{tabular}{lcccc}
\hline $\begin{array}{l}\text { Festival } \\
\text { components }\end{array}$ & $\begin{array}{c}\text { Factor 1: } \\
\text { Shopping } \\
\text { opportunities } \\
\text { (SO) }\end{array}$ & $\begin{array}{c}\text { Factor 2: } \\
\text { Shows and } \\
\text { accommodation } \\
\text { (SA) }\end{array}$ & $\begin{array}{c}\text { Factor 3: } \\
\text { Accessibility } \\
\text { and } \\
\text { affordability } \\
\text { (AA) }\end{array}$ & $\begin{array}{c}\text { Factor 4: } \\
\text { Gastronomy } \\
\text { (G) }\end{array}$ \\
\hline Retail shopping & 0.92 & - & - & - \\
Shopping at stalls & 0.74 & - & - & - \\
Art and art work & 0.73 & - & - & - \\
Theatre productions & - & 0.88 & - & - \\
Accommodation & - & 0.75 & - & - \\
Music productions & - & 0.63 & - & - \\
Parking & - & - & 0.85 & - \\
$\begin{array}{l}\text { Seating on the } \\
\text { festival grounds }\end{array}$ & - & - & 0.78 & - \\
Entrance fees & - & - & 0.56 & - \\
Beverages & - & - & - & 0.89 \\
Food and restaurants & - & - & - & 0.84 \\
Reliability coefficient & 0.84 & 0.72 & 0.67 & 0.85 \\
$\begin{array}{l}\text { Average inter-item } \\
\text { correlation }\end{array}$ & 0.64 & 0.47 & 0.40 & 0.74 \\
Mean value & 3.93 & 4.21 & 4.11 & 4.29 \\
\hline
\end{tabular}

well-fitted model. The RMSEA value was 0.073 with $90 \%$ confidence (between 0.071 and 0.081 , which is acceptable); the CFI was 0.875 , which also means that it is acceptable; and the relative/normed $\chi^{2}$ was 4.219 , which is also acceptable.

Finally, regarding the factor loyalty, respondents indicated that they are extremely loyal to the festival $(\bar{x}=4.68)$; therefore, this factor was used as the dependent variable in the SEM to follow.

\section{Results from the structural equation modelling model}

For the SEM model, the festival loyalty (FL) factor (Table 3) was used as the dependent variable. A SEM model was developed to show which individual 'festivalscape' factors, as identified in Table 1, and individual influential decisionmaking factors, as identified in Table 2, had a relation to festival loyalty (see hypotheses below). In preparation for the SEM, Spearman's rank order correlations were calculated to describe the strength and direction of the linear relationship between continuous variables (Pallant 2016). This was done because SEM works like a regression by taking the correlation of the independent variables into account for the standardised regression weights to be similar to the semi-partial correlation and ordinary regression.

Cohen et al. (2013) suggest the following guidelines to interpret the correlation coefficient values between 0 and 1 : small effect: $r_{\mathrm{s}}=0.10-0.29$; medium effect: $r_{\mathrm{s}}=0.30-0.49$ and

TABLE 2: Results from the factor analysis regarding the influential decision-making factors to attend the festival.

\begin{tabular}{|c|c|c|c|c|c|}
\hline Aspects influencing the decision to attend Aardklop & $\begin{array}{l}\text { Factor 1: Festival } \\
\text { attractiveness } \\
\text { (FA) }\end{array}$ & $\begin{array}{l}\text { Factor 2: Festival } \\
\text { rebranding } \\
\text { (FR) }\end{array}$ & $\begin{array}{l}\text { Factor 3: Art } \\
\text { purchasing and } \\
\text { well-being (AW) }\end{array}$ & $\begin{array}{c}\text { Factor 4: } \\
\text { Festival getaway } \\
\text { (FG) }\end{array}$ & $\begin{array}{l}\text { Factor 5: Festival } \\
\text { repositioning } \\
\text { (FR) }\end{array}$ \\
\hline To see well-known Afrikaans artists & 0.79 & - & - & - & - \\
\hline The festival is value for money & 0.68 & - & - & - & - \\
\hline It is the closest festival to me & 0.56 & - & - & - & - \\
\hline To attend flagship productions at the festival & 0.53 & - & - & - & - \\
\hline To experience the unique atmosphere of the festival & 0.46 & - & - & - & - \\
\hline New festival slogan & - & 0.92 & - & - & - \\
\hline New festival trademark (logo) & - & 0.90 & - & - & - \\
\hline Greater community involvement and projects & - & 0.79 & - & - & - \\
\hline Marketing initiatives & - & 0.76 & - & - & - \\
\hline New festival management & - & 0.73 & - & - & - \\
\hline Compilation of the festival programme & - & 0.63 & - & - & - \\
\hline Relocation of the festival to the original festival grounds & - & 0.53 & - & - & - \\
\hline Attending arts festivals such as Aardklop contributes to my overall well-being & - & - & 0.73 & - & - \\
\hline Attending arts festivals forms part of my lifestyle & - & - & 0.67 & - & - \\
\hline To socialise and meet new people & - & - & 0.57 & - & - \\
\hline To relax & - & - & - & 0.85 & - \\
\hline To escape from my daily routine & - & - & - & 0.83 & - \\
\hline Attending Aardklop is an annual commitment & - & - & - & 0.56 & - \\
\hline Retention of the festival in Potchefstroom & 0.79 & - & - & - & 0.82 \\
\hline To see a variety of high quality productions & - & - & - & - & 0.72 \\
\hline The positioning of the new Aardklop festival & - & - & - & - & 0.64 \\
\hline Adapted and more affordable entrance fee to the festival grounds & - & - & - & - & 0.46 \\
\hline Reliability coefficient & 0.84 & 0.92 & 0.78 & 0.78 & \\
\hline Average inter-item correlation & 0.48 & 0.62 & 0.49 & 0.56 & 0.50 \\
\hline Mean value & 4.42 & 4.03 & 3.77 & 4.37 & 4.48 \\
\hline
\end{tabular}


TABLE 3: Results from the factor analysis regarding visitor loyalty (dependent variable).

\begin{tabular}{lc}
\hline Loyalty towards the festival & Festival loyalty (FL) \\
\hline I will comment positively on the festival & 0.91 \\
I will attend the festival again next year & 0.90 \\
I will recommend the festival to family and friends & 0.88 \\
Reliability coefficient & 0.87 \\
Average inter-item correlation & 0.71 \\
Mean value & 4.68 \\
\hline
\end{tabular}

large effect: $r_{\mathrm{s}}=0.50-1.00$. The results indicated that all four 'festivalscape' factors and five decision-making factors had medium to high effects on festival loyalty. Moreover, the factors had a significant relationship, not only with festival loyalty but also with each other. The SEM, however, indicates the unique relationship between each factor and festival loyalty. A CFI closer to 1, RMSEA closer to 0 (preferably $\leq 0.08$ ) and a relative/normed $\chi^{2}\left(\chi^{2} / \mathrm{df}\right.$, i.e. the chi-square index divided by its degrees of freedom) above 0.50 mean a good fit for a model (Blunch 2008).

For the model, the following hypotheses were proposed:

H0 (1a): Festival attractiveness is not related to festival loyalty. H1a: Festival attractiveness is related to festival loyalty.

H0 (1b): Festival rebranding is not related to festival loyalty. H1b: Festival rebranding is related to festival loyalty.

H0 (1c): Art purchasing and well-being are not related to festival loyalty.

H1c: Festival enhancement is related to festival loyalty.

H0 (1d): Festival getaway is not related to festival loyalty. H1d: Festival getaway is related to festival loyalty.

H0 (1e): Festival repositioning is not related to festival loyalty. H1e: Festival repositioning is related to festival loyalty.

H0 (1f): Shopping opportunities are not related to festival loyalty.

H1f: Shopping opportunities are related to festival loyalty.

H0 (1g): Shows and accommodation are not related to festival loyalty.

H1g: Productions and accommodation are related to festival loyalty.

H0 (1h): Accessibility and affordability are not related to festival loyalty.

H1h: Accessibility and affordability are related to festival loyalty.

H0 (1i): Gastronomy is not related to festival loyalty.

H1i: Gastronomy is related to festival loyalty.

The hypotheses deduced and tested in the present research are illustrated in Figure 2.

The RMSEA value was 0.062 with $90 \%$ confidence (between 0.055 and 0.070 , which is acceptable). Values for the CFI should be between 0.0 and 1.0; values closer to 1.0 indicate a good fit. The CFI was 0.994 , which means that it is acceptable. Moreover, the relative/normed $\chi^{2}$ is advised to be between 2.0 and 5.0. Therefore, the value of 2.475 is also acceptable. Overall, the fit indices indicated a well-fitted model. Table 4 shows the maximum likelihood estimates, the regression

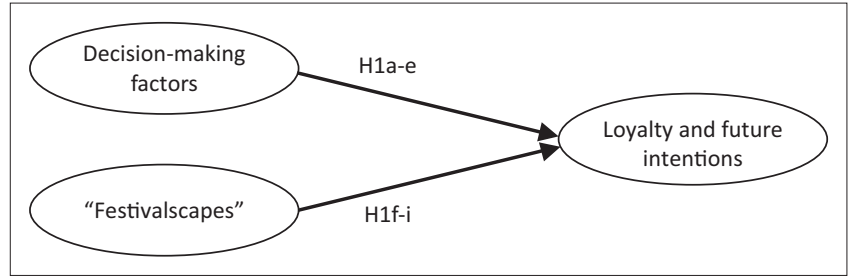

FIGURE 2: Hypothesised model.

TABLE 4: Standardised regression weights, estimates and $p$-value.

\begin{tabular}{lccc}
\hline Hypothesis & Factors & Standardised regression weights & Sig. level \\
\hline $\mathrm{H}_{1 \mathrm{a}}$ & $\mathrm{FL}<---\mathrm{FA}$ & 0.144 & $0.032^{*}$ \\
$\mathrm{H}_{1 \mathrm{~b}}$ & $\mathrm{FL}<---\mathrm{FR}$ & 0.030 & 0.624 \\
$\mathrm{H}_{1 \mathrm{c}}$ & $\mathrm{FL}<---\mathrm{AW}$ & 0.002 & 0.978 \\
$\mathrm{H}_{1 \mathrm{~d}}$ & $\mathrm{FL}<---\mathrm{FG}$ & 0.197 & $0.001^{*}$ \\
$\mathrm{H}_{1 \mathrm{e}}$ & $\mathrm{FL}<---\mathrm{FR}$ & -0.020 & 0.748 \\
$\mathrm{H}_{1 \mathrm{f}}$ & $\mathrm{FL}<---\mathrm{SO}$ & 0.050 & 0.402 \\
$\mathrm{H}_{1 \mathrm{~g}}$ & $\mathrm{FL}<---\mathrm{SA}$ & -0.041 & 0.435 \\
$\mathrm{H}_{1 \mathrm{~h}}$ & $\mathrm{FL<---AA}$ & 0.169 & $0.001^{*}$ \\
$\mathrm{H}_{1 \mathrm{i}}$ & $\mathrm{FL}<---\mathrm{G}$ & 0.113 & $0.038^{*}$ \\
\hline
\end{tabular}

$\mathrm{FL}$, festival loyalty; FA, festival attractiveness; FR, festival rebranding; AW, art purchasing and well-being; $F G$, festival getaway; $F R$, festival repositioning; SO, shopping opportunities; SA, shows and accommodation; AA, accessibility and affordability; G, Gastronomy.

*, statistically significant difference: $p \leq 0.05$.

weights of the structural parts of the model and the statistical significance of the factors.

As Table 4 shows, the decision-making factors festival attractiveness (0.144) and festival getaway (0.197) and the 'festivalscape' factors accessibility and affordability (0.169) and gastronomy (0.113) had significant positive standardised regression weights at a $5 \%$ level of significance $(p<0.05)$. The results, therefore, indicate that $\mathrm{H} 1 \mathrm{a}, \mathrm{H} 1 \mathrm{~d}, \mathrm{H} 1 \mathrm{~h}$ and $\mathrm{H} 1 \mathrm{i}$ are supported at a level of significance $(p \leq 0.05)$ and that these factors had a unique relation to festival loyalty. Thus, if the aim is to increase loyalty to the festival, the focus should be on managing those aspects.

\section{Findings and implications}

This research has the following findings and implications:

Firstly, the results confirm that the unique offerings of the festival influence the combination of 'festivalscapes' and how visitors rate them. This research identified four 'festivalscapes' (in order based on the level of satisfaction): gastronomy, shows and accommodation, accessibility and affordability and shopping opportunities. The high ratings of the factors indicate that respondents are satisfied with both the primary and secondary festival offerings (see Figure 1). Gastronomy was, similar to food and beverages, identified by Van Zyl (2008); however, this secondary festival offering has not been identified as a prominent 'festivalscape' to confirm the findings by Viljoen et al. (2018) that culinary offerings play a significant role in visitors' overall festival experience. Shows and accommodation is also supported by Van Zyl's (2008) findings, whereas Viljoen and Kruger (2019) also identified accessibility as an important 'festivalscape' factor. The combination with affordability is, however, novel to the present research, although 'general management' that 
includes these aspects was identified in previous research (Kruger et al. 2010). Finally, the importance of shopping opportunities as a 'festivalscape' factor supports the findings by Kruger and Saayman (2018c) that the stalls selling arts and crafts, as well as food and drinks, play an essential role in enhancing the overall festival experience. Festival organisers should consider these 'festivalscape' factors to ensure a satisfying visitor experience and they should, therefore, be intensively emphasised in marketing messages, as these factors greatly influence visitors' decision-making process (Figure 1). This implies, firstly, that the organisers must ensure that flagship and quality productions are featured and included in the festival programme but at affordable prices. Practical aspects surrounding the festival, for example accommodation options and accessibility, should also feature in marketing campaigns. Secondly, it implies that the organisers must enhance gastronomy and shopping opportunities, implying a variety of good, exclusive products at affordable prices and that the variety sold at the stalls should mainly comprise locally produced, quality food and beverage options, as well as arts, crafts and products that reflect the unique South African culture, but with less repetition of the same products (including arts and crafts).

Secondly, the results confirmed that the repositioning and rebranding of the festival significantly influenced visitors' decision to attend the festival. Five decision-making factors were identified (in order of importance): festival repositioning, festival attractiveness, festival rebranding, festival getaway and art purchasing and well-being. Although festival repositioning and festival rebranding are novel to this research, previous research conducted at South African national arts festivals confirms festival attractiveness and festival getaway. In the majority of arts festival research, festival attractiveness features as the main pull motive to attend (Botha et al. 2012:22-44; Kruger \& Saayman 2012:147-162, 2016:392-408; Kruger et al. 2010:1-26, 2011:511-526; Saayman 2011:109-120; Van Zyl \& Botha 2003:213-222; Viviers et al. 2013:211-229; Viviers \& Slabbert 2014:1-18), whereas festival getaway encompasses to escape and to socialise, which are two other prominent motives in both national and international festival research. Art purchasing and well-being is another original decision-making factor of this research. Art purchasing supports the 'festivalscape' factor shopping opportunities, whereas wellbeing implies that attending arts festivals forms part of people's lifestyle - an aspect that has not yet been identified in arts festival research but plays an important role in visitors' decision. Visitors, therefore, seek enriching experiences on both personal and interpersonal levels, which supports the notion that visitors' decision-making process starts with a need. However, this research shows that these needs are also intrapersonal and that arts festivals provide the opportunity to fulfil this need.

Thirdly, according to Yang et al. (2011), festival loyalty encompasses visitors' willingness to comment positively on the festival, recommend it to others and return in the future. The high mean value obtained for this factor indicates that visitors to the festival can be regarded as very loyal. To retain loyal visitors implies that festival organisers must know the needs of the market it attracts.

Fourthly, the results of the SEM revealed that the motives festival attractiveness and festival getaway, as well as the 'festivalscape' factors accessibility and affordability and gastronomy, had the strongest influence on festival loyalty. These findings thereby support the notion that quality, value and satisfaction should be examined to understand visitors' behaviour and their intention to return (Kruger \& Saayman 2017:204-223, 2018a:1-16, 2018b:237-254; Lee 2016:187-196; Lee et al. 2007:463-481; Yoon et al. 2010:335-342), and that satisfaction leads to customer loyalty (Kruger \& Saayman 2018a:1-16, 2018b:237-254, 2018c; Smith et al. 2010:17-35). In addition, confirming the findings by Kruger and Saayman (2018a), festival attributes, in other words, the distinct nature and characteristics of the festival, had a strong relationship with festival loyalty along with festival getaway, which confirms the findings by Fourie and Kruger (2015). The significant influence of accessibility and affordability is confirmed by Kruger et al. (2010), whereas gastronomy as an influential factor has not been identified in arts festival research yet, although it has been identified in culinary festival studies (Viljoen \& Kruger 2019); however, the relationship between gastronomy and festival loyalty has not been established yet.

Finally, although the festival rebranding and festival reposition factors were identified as major factors influencing visitors' decision to attend Aardklop, the SEM model showed that they had no significant or unique relationship with festival loyalty. Therefore, festival organisers and marketers who have to (or are planning to) rebrand festivals should plan this process and changes around the unique offerings, festival features and experiences. The process must enhance these offerings, as they have the greatest influence on festival loyalty.

\section{Conclusion}

The aim of this research was twofold: firstly, to determine the key 'festivalscapes' and decision-making factors, as well as how the rebranding process of a national arts festival in South Africa influences these aspects; secondly, to determine the relationship between these factors and visitors' behavioural intentions. Based on the results, it is clear that several contributions are evident. Novel factors were identified about 'festivalscapes', for example affordability, as well as the combination of factors. Also, the importance of gastronomy and shopping opportunities was highlighted in the research. This is also important from an economic point of view because it stresses the fact that festival visitors have a need and are willing to spend money on these aspects. Another major contribution is evident in the role that rebranding has played in visitors' decision-making - an aspect that has, to the authors' knowledge, not been explored or investigated yet. The third contribution was to identify the factors that influence festival loyalty. In a time where there is an increase in festivals globally, which implies greater competition, more and more festivals are finding themselves in the decline phase of their product's lifecycle. These festivals 
have one of two options, namely to terminate or to rebrand and reposition the festival. In South Africa, many festivals chose the first option, but in the case of Aardklop, choosing the second option proved to be successful. However, from a sustainability point of view, this implies continuous research to ensure that the needs of the festival visitors are met.

\section{Acknowledgements}

This work is based on the research supported by the National Research Foundation (NRF). The authors are grateful to the organisers of the festival for allowing the research to be conducted as well as to all the fieldworkers and respondents who graciously formed part of the research. This research is dedicated to my colleague, friend and mentor, Melville Saayman, who sadly passed away. He will continue to inspire me in my research. This research forms part of his legacy and is a testimony to his love for the arts and his enduring efforts to help sustain national arts festivals in South Africa. He will forever be in my heart.

\section{Competing interests}

The authors declare that they have no financial or personal relationships that may have inappropriately influenced them in presenting this article.

\section{Authors' contributions}

M.K. conceptualised the research idea, structured the article, developed the measuring instrument and coordinated the survey. She further performed all statistical analyses and quality insurance of the overall document. M.S., as co-author, helped conceptualise the research idea and helped design the questionnaire.

\section{Funding}

This research received no specific grant from any funding agency in the public, commercial or not-for-profit sectors.

\section{Disclaimer}

Any opinion, findings and conclusion or recommendation expressed in this article are that of the authors and the NRF does not accept any liability in this regard.

\section{Data availability statement}

The data that support the findings of this study are available on request from the corresponding author (M.K.). The data are not publicly available due to ethical restrictions.

\section{References}

Aardklop., 2018, Aardklop! Kom fees jouplek vol!, viewed 10 January 2019, from https://aardklop.co.za/.

Blunch, N.J., 2008, Introduction to structural equation modelling using SPSS and AMOS, Sage, London.

Botha, K., Slabbert, E., Rossouw, R. \& Viviers, P.A., 2011, 'Expenditure-based segmentation of visitors to Aardklop National Arts Festival', South African Theatre Journal 25(2), 142-166. https://doi.org/10.1080/10137548.2011.639168
Botha, K., Slabbert, E. \& Viviers, P., 2014, 'Towards a ticket purchase behaviour model for South African arts festivals', Journal of Contemporary Management 11(1), 324-348.

Botha, K., Viviers, P.A. \& Slabbert, E., 2012, 'What really matters to the audience: Analysing the key factors contributing to arts festival ticket purchases', South African Theatre Journal 26(1), 22-44. https://doi.org/10.1080/10137548.2012. 754080

Chen, P.C., 2011, Festivals: Predicting attendance intention with decision-making factors, Indiana University, Bloomington.

Cohen, J., 1988, Statistical power analysis for the behavioral sciences, 2nd edn., Hillsdale, Erlbaum, NJ.

Cohen, J., Cohen, P., West, S.G. \& Aiken, L.S., 2013, Applied multiple regression/ correlation analysis for the behavioral sciences, Routledge, New York.

Duman, T. \& Mattila, A.S., 2005, 'The role of affective factors on perceived cruise vacation value', Tourism Management 26(3), 311-323. https://doi.org/10.1016/j. tourman.2003.11.014

Fourie, M. \& Kruger, M., 2015, “"Festivalscape" factors influencing visitors' loyalty to an agri-festival in South Africa', Acta Commercii 15(1), 1-11. https://doi. org/10.4102/ac.v15i1.307

Getz, D., 2005, Event management and event tourism, 2nd edn., Cognizant Communications Corp, Elmsford, NY.

Hauptfleisch, T., 2006, 'Eventifying identity: Festivals in South Africa and the search for cultural identity', New Theatre Quarterly 22(2), 181-198. https://doi.org/10.1017/ S0266464X0600039X

Kim, M.J., Lee, C.K., Petrick, J.F. \& Hahn, S.S., 2018, 'Factors affecting international event visitors' behavioral intentions: The moderating role of attachment avoidance', Journal of Travel \& Tourism Marketing 35(8), 1027-1042 https://doi. org/10.1080/10548408.2018.1468855

Kitshoff, H.V.Z., 2005, 'Die opkoms, dinamika en betekenis van die Klein Karoo Nasionale Kunstefees: 1995-2005', PhD thesis, University of Stellenbosch, Stellenbosch, South Africa.

Krejcie, R.B. \& Morgan, D.W., 1970, 'Determining sample size for research activities', Educational and Psychological Measurement 30, 607-610, viewed 14 December 2018, from http://home.kku.ac.th/sompong/guest_speaker/KrejcieandMorgan_ article.pdf.

Kruger, M. \& Saayman, M., 2012, 'When do festinos decide to attend an arts festival? An analysis of the Innibos National Arts Festival', Journal of Travel \& Tourism Marketing 29(2), 147-162. https://doi.org/10.1080/10548408.2012. 648538

Kruger, M. \& Saayman, M., 2016, 'Are you willing to pay more for the arts?', Journal of Economic and Financial Sciences 9(2), 392-408. https://doi.org/10.4102/jef. v9i2.48

Kruger, M. \& Saayman, M., 2017, 'Segmenting beyond behavioural intentions: Fine tuning music festival visitors' music appreciation', International Journal of Event tuning music festival visitors music appreciation', International Journal of Event
and Festival Management 8(2), 204-223. https://doi.org/10.1108/JEFM-092016-0064

Kruger, M. \& Saayman, M., 2018a, 'All that jazz': The relationship between music festival visitors' motives and behavioural intentions', Current Issues in Tourism https://doi.org/10.1080/13683500.2018.1451496

Kruger, M. \& Saayman, M., 2018c, 'Arts festival offerings: What do market segments prefer?', Event Management. https://doi.org/10.3727/152599518X15403853 721385

Kruger, M. \& Saayman, M., 2018b, 'From drab to fab: Segmenting visitors to a décor and design exhibition based on their behavioral intentions', Event Management 22(2), 237-254. https://doi.org/10.3727/152599518X15173355843370

Kruger, M., Saayman, M. \& Ellis, S., 2011, 'Segmenting by genres: The case of the Aardklop National Arts Festival', International Journal of Tourism Research 13(1) 511-526. https://doi.org/10.1002/jtr.818

Kruger, M., Saayman, M. \& Ellis, S.M., 2010, 'Does loyalty pay? First-time versus repeat visitors at a national arts festival', Southern African Business Review 14(1), 1-26. https://doi.org/10.4102/ac.v14i1.220

kykNET, 2017, kykNETFiëstas 2018: Hier is die wenners, viewed 15 December 2018, from https://kyknet.dstv.com/blad/home/kyknet-fiestas-2018-hier-is-diewenners/nuus.

Lee, J., Graefe, A.R. \& Burns, R.C., 2007, 'Examining the antecedents of destination loyalty in a forest setting', Leisure Sciences 29(5), 463-481. https://doi.org/ 10.1080/01490400701544634

Lee, Y.K., 2016, 'Impact of government policy and environment quality on visitor loyalty to Taiwan music festivals: Moderating effects of revisit reason and occupation type', Tourism Management 53, 187-196. https://doi.org/10.1016/ occupation type', 10 ourisman.2015.10.004

Maeng, H.Y., Jang, H.Y. \& Li, J.M., 2016, 'A critical review of the motivational factors for festival attendance based on meta-analysis', Tourism Management Perspectives 17, 16-25. https://doi.org/10.1016/j.tmp.2015.10.003

Moutinho, L., 1987, 'Consumer behaviour in tourism', European Journal of Marketing 21(10), 5-44. https://doi.org/10.1108/EUM0000000004718

News24, 2017, '5 surprising facts about Afrikaans', viewed 20 December 2018, from https://www.news24.com/You/Sponsored-Content/5-surprising-facts-aboutafrikaans-20171101.

Pallant, J., 2016, SPSS survival manual, McGraw-Hill Education, London.

Pretorius, S.C., Viviers, P. \& Botha, K., 2014, 'Is it still about the arts? The perceived contribution of KKNK to the arts', South African Theatre Journal 27(3), 159-182. https://doi.org/10.1080/10137548.2014.910964 
Pretorius, S.C., Viviers, P. \& Botha, K., 2016, 'The perceived contribution of three South African arts festivals to the development of the arts and tourism', Tourism. African Journal for Physical Activity and Health Sciences (AJPHES) 22(12), 290-305.

Quinlan, C., Babin, B., Carr, J., Griffin, M. \& Zikmund, W., 2015, Business research methods, 1st edn., Cengage Learning, Andover, MA.

Saayman, M., 2011, 'Motives for attending the Cultivaria Arts festival', South African, Journal for Research in Sport, Physical Education and Recreation 33(1), 109-120. https://doi.org/10.4314/sajrs.v33i1.65492

SAHO, 2018, 'Afrikaans is declared as an official language of South Africa', viewed 19 December 2018, from https://www.sahistory.org.za/dated-event/afrikaansdeclared-official-language-south-africa.

Smith, S., Costello, C. \& Muenchen, R.A., 2010, 'Influence of push and pull motivations on satisfaction and behavioral intentions within a culinary tourism event', Journal of Quality Assurance in Hospitality \& Tourism 11(1), 17-35. https://doi.org/ $10.1080 / 15280080903520584$

Snowball, J.D., 2005, 'Art for the masses? Justification for the public support of the arts in developing countries-two arts festivals in South Africa', Journal of Cultural Economics 29(2), 107-125. https://doi.org/10.1007/s10824-005-5064-5

Snowball, J.D. \& Antrobus, G.G., 2001, 'Measuring the value of the arts to society: The importance of the value of externalities for lower income and education groups in South Africa', South African Journal of Economics 69(4), 752-766. https://doi. org/10.1111/j.1813-6982.2001.tb00034.x

Snowball, J.D. \& Willis, K.G., 2006, 'Estimating the marginal utility of different sections of an arts festival: The case of visitors to the South African National Arts Festival', Leisure Studies 25(1), 43-56. https://doi.org/10.1177/004728759203000303

SPSS version 25, 2018, Computer software, IBM, Chicago, IL.

TREES, 2018,'A marketing and economic impact analysis of Aardklop National Arts Festival 2017', Unpublished report, TREES: North-West University, South Africa.

Um, S. \& Crompton, J.L., 1991, 'The roles of perceived inhibitors and facilitators in pleasure travel destination decisions', Journal of Travel Research 30(3), 18-25. https://doi.org/10.1177/004728759203000303

Van Heerden, C. \& Saayman, M., 2018, 'Sustainability of a national arts festival: An application of a data envelopment analysis approach', Tourism Economics, viewed 15 December 24(5), 576-592. https://doi.org/10.1177/1354816618762186
Van Zyl, C., 2008, 'A conjoint analysis of festival attributes for successful positioning of selected arts festivals in South Africa', Southern African Business Review 12(3), 128-155.

Van Zyl, C. \& Botha, C., 2003, 'Motivational factors of local residents to attend the arts festivals', Event Management 8(4), 213-222. https://doi.org/10.3727/15259950 31436818

Van Zyl, C. \& Strydom, J.W., 2007, 'The use of game theory to determine the optimum market position of selected arts festivals in South Africa', Southern African Business Review11(3), 121-143.

Viljoen, A., Kruger, M. \& Saayman, M., 2018, 'The art of tastings: Enhancing the arts festival experience', International Journal of Festival and Event Management 9(3) 246-265. https://doi.org/10.1108/IJEFM-03-2018-0023

Viljoen, A. \& Kruger, M. \& Saayman, M., 2019, 'Distinguishing chalk from cheese A 3-I "festivalscape" typology of cheese festival visitors', Event Management 23(1), 427-445. https://doi.org/10.3727/152599518X15403853721501

Viljoen, A., Kruger, M. \& Saayman, M., 2017, 'The 3-S typology of South African culinary festival visitors', International Journal of Contemporary Hospitality Management 29(6), 1560-1579. https://doi.org/10.1108/IJCHM-09-2015-0464

Viviers, P.A., Botha, K. \& Perl, C., 2013, 'Push and pull factors of three Afrikaans arts festivals in South Africa', South African Journal for Research in Sport, Physical Education and Recreation 35(2), 211-229.

Viviers, P.A. \& Slabbert, E., 2014, 'Should arts festivals focus on push or pull factors in marketing efforts?', African Journal of Hospitality, Tourism and Leisure 3(2), $1-18$.

Woodside, A.G. \& MacDonald, R., 1994, 'General system framework of customer choice processes of tourism services', Spoilt for Choice 31-59, viewed 15 December 2018, from http://hdl.handle.net/2345/3020.

Yang, J., Gu, Y. \& Cen, J., 2011, 'Festival tourists' emotion, perceived value, and behavioral intentions: A test of the moderating effect of festivalscape', Journal of Convention \& Event Tourism 12(1), 25-44. https://doi.org/10.1080/15470148.2010. 551292

Yoon, Y.S., Lee, J.S. \& Lee, C.K., 2010, 'Measuring festival quality and value affecting visitors' satisfaction and loyalty using a structural approach', International Journal of Hospitality Management 29(2), 335-342. https://doi.org/10.1016/j.ijhm.2009. 10.002 